\title{
Development and application of ELISA for the detection of IgG antibodies to lymphocytic choriomeningitis virus
}

\author{
K. LAPOŠOVÁ ${ }^{1}$, L. LUKÁČIKOVÁ ${ }^{1}$, I. OVEČKOVÁ ${ }^{1}$, S. PASTOREKOVÁ ${ }^{1}$, J. ROSOCHA², D. KUBA ${ }^{3}$, L. BEŇA ${ }^{4}$, \\ J. TOMÁŠKOVÁ ${ }^{*}$
}

\begin{abstract}
${ }^{1}$ Department of Molecular Medicine, Institute of Virology, Biomedical Research Centre, Slovak Academy of Sciences, Dúbravská cesta 9, 84505 Bratislava, Slovak Republic; ${ }^{2}$ UPJŠ FM and LP UH Associated Tissue Bank, 04011 Košice, Slovak Republic; ${ }^{3}$ National Transplantation Organization, 83303 Bratislava, Slovak Republic; ${ }^{4}$ Department of Transplantation, L. Pasteur University Hospital, 04166 Košice, Slovak Republic
\end{abstract}

Received April 24, 2015; revised November 10, 2015; accepted April 15, 2016

\begin{abstract}
Summary. - Lymphocytic choriomeningitis virus (LCMV) is a neglected human pathogen, which can cause severe illnesses in humans. The most vulnerable are the human foetus and immunosuppressed individuals. Since there is no commercially available enzyme-linked immunosorbent assay (ELISA) for the diagnosis of anti-LCMV antibodies in human sera, we developed a sandwich ELISA method detecting anti-nucleoprotein IgG antibodies, using a specific monoclonal anti-nucleoprotein antibody and cells persistently infected with LCMV strain MX as antigen. In the present study we show standardization of this ELISA protocol, determination of its clinical specificity and sensitivity and its application on 30 clinical samples from multiorgan donors. Comparison of these results to the indirect immunofluorescence antibody test (IFA) demonstrates that ELISA is more sensitive. The developed ELISA assay provides a fast, simple and efficient tool for the clinical detection of anti-nucleoprotein antibodies in human sera.
\end{abstract}

Keywords: lymphocytic choriomeningitis virus; ELISA; human serum; IgG antibodies

\section{Introduction}

Lymphocytic choriomeningitis virus, a prototype arenavirus, is a rodent-borne pathogen carried mostly by house mouse (Mus musculus), but it has also been detected in other rodent species, such as hamsters, rats, and guinea pigs. Persistently infected rodents shed the virus in urine, faeces, milk, saliva, and semen (Jamieson et al., 2006). Humans become infected through the contact with contaminated material or by inhalation of aerosolized viral particles. In immunocompetent adults, infections are mostly asymptomatic or mild,

*Corresponding author. E-mail: jana.tomaskova@savba.sk; phone: +421-2-59302439.

Abbreviations: $\mathrm{Ab}=$ antibody; ELISA = enzyme-linked immunosorbent assay; IFA = indirect immunofluorescence antibody test; LCMV = lymphocytic choriomeningitis virus; $\mathrm{NP}=$ nucleoprotein of LCMV with flu-like symptoms, but diseases of the CNS, such as aseptic meningitis, can also occur (Barton and Mets, 2001). In contrast to the self-limited acquired postnatal LCMV infection, prenatal infection leads to an increased risk of spontaneous abortion, severe CNS defects (hydrocephalus, microcephaly), and chorioretinitis of the foetus (Bonthius et al., 2007). Moreover, recently reported transmissions of LCMV through infected solid organ transplants revealed a risk to immunocompromised individuals. Six clusters of organ transplant-associated LCMV and LCMV-like arenavirus transmissions have been documented in the USA and Australia before April 2013. Of 24 recipients (including kidney, liver, lung, and cornea recipients), 15 died of multisystem organ failure. Survivors of these infections were treated with oral ribavirin and reduction of immunosuppressive therapy. Interestingly, LCMV could not always be detected in donors by RT-PCR or serology testing (Fischer et al., 2006; CDC, 2008; Palacios et al., 2008; MacNeil et al., 2012; Schafer et al., 2014). The most commonly used serological tests for detec- 
tion of specific anti-LCMV IgM or IgG antibodies are ELISA and indirect immunofluorescence assay (IFA) (OIE, 2006). Complement fixation test is insensitive and should not be used (Mets et al., 2000). PCR can be utilized for the detection of viral RNA in the serum or cerebrospinal fluid (OIE, 2006). In terms of congenital infection, several authors have noted that LCMV is an underreported and underdiagnosed teratogen, whose true incidence is not defined (Jamieson et al., 2006). More than 70 cases of children with congenital LCMV infection have been reported worldwide (Barton et al., 2002; Bonthius et al., 2007). Serological studies indicate that approximately $5 \%$ of the human population in the United States has LCMV antibodies (Park et al., 1997a). In a study from an inland city in Argentina, an overall LCMV seroprevalence was 3.3\% (Riera et al., 2005). A seropositivity rate of $4 \%$ was detected among inhabitants of Nova Scotia (Marrie and Saron, 1998), 1.7\% in the Community of Madrid in Spain (Lledó et al., 2003), 3.5\% in the inner city of Birmingham (Park et al., 1997b). The prevalence of LCMV antibodies on the Croatian island of Vir was found to be $36 \%$ (detected by IFA) and 13\% (by complement fixation) (Dobec et al., 2006). The study from 1973 proved that $9.1 \%$ of the rural population in southern Germany had neutralizing antibodies (Ackermann, 1973). Of the serum samples of nearly 500 forestry workers from Trentino (Italy) tested by IFA, 12 (2.5\%) were positive for specific LCMV IgG (Kallio-Kokko et al., 2006). Immunoprecipitation analysis of 56 human sera in Slovakia revealed $37.5 \%$ seropositivity for anti-nucleoprotein (anti-NP) IgG (Reiserová et al., 1999).

Since there is no commercially available ELISA kit for the detection of LCMV-specific antibodies in human sera, we developed a sensitive method using an anti-NP monoclonal antibody and cells persistently infected with the LCM virus. In this paper, we outline this ELISA protocol, determine its clinical sensitivity and specificity, and describe its application for the detection of LCMV IgG antibody seroprevalence in a group of multiorgan donors in comparison to the immunofluorescence antibody assay.

\section{Materials and Methods}

Cell culture and virus. BHK21 cells were infected with lymphocytic choriomeningitis virus strain MX (designated BHK/ MX) by filtered cell free extract as described earlier (van der Zeijst et al., 1983). Noninfected BHK21 cells cultured in parallel were used as control. The cells were grown in Dulbecco modified Eagle medium (DMEM) with 10\% FCS, 2 mmol/l L-glutamine, and 160 $\mu \mathrm{g} / \mathrm{ml}$ gentamicin and maintained at $37^{\circ} \mathrm{C}$ in a humidified $5 \% \mathrm{CO}_{2}$ atmosphere.

Collection of samples. Sera samples were collected by MVDr. Ján Rosocha, CSc. from the Faculty of Medicine, Pavol Jozef Šafárik University and Louis Pasteur University Hospital Associated Tis- sue Bank in Košice and by MUDr. L'uboslav Beňa, PhD. from the Department of Transplantation of the LP UH in Košice, Slovakia. Sera used for the determination of the cut-off value were collected by MUDr. Daniel Kuba, PhD. from the National Transplantation Organization, Slovakia. Anti-LCMV antibody-positive KH serum from a mammary carcinoma patient was described previously (Závada et al., 1972).

Antibodies. Mouse monoclonal antibodies M16 and M87 detect different epitopes of LCMV NP (Pastorekova et al., 1992; Tomaskova et al., 2011). M16 was labelled with Alexa Fluor 488 using Molecular Probes' Alexa Fluor ${ }^{\circledR} 488$ antibody labelling kit (Invitrogen, UK) according to the manufacturer's instructions. Secondary antibodies used were goat anti-human IgG (Fc-specific)peroxidase antibody, goat anti-mouse IgG (Fc-specific)-peroxidase antibody (both from Sigma, USA) and goat anti-human IgG $(\mathrm{H}+\mathrm{L})$ / Alexa Fluor 568 (Invitrogen).

Determination of nucleoprotein concentration in BHK/MX protein extracts. For protein extraction, BHK/MX and BHK21 cells were lysed in ice-cold lysis buffer $(50 \mathrm{mmol} / \mathrm{l}$ Tris $\mathrm{pH} 7.5,150$ $\mathrm{mmol} / 1 \mathrm{NaCl}, 1 \%$ Triton X-100, $0.1 \%$ sodium deoxycholate) containing inhibitors of proteases (Roche Applied Science, Germany). Antigen (NP of LCMV) concentration was set indirectly by the ELISA method where 96-well high binding plate (Greiner Bio-One, Austria) was coated with $\mathrm{BHK} / \mathrm{MX}$ and $\mathrm{BHK} 21$ protein extracts. After incubation at $37^{\circ} \mathrm{C}$ overnight, the plates were washed three times with $0.1 \%$ Tween 20 in PBS (Tween-PBS). Then, each well of the plates was blocked for $1.5 \mathrm{hr}$ with $10 \%$ nonfat dry milk in $0.1 \%$ Tween 20 in PBS (200 $\mu$ l per well) and washed 3 times with TweenPBS. After this step, plates were incubated for $1 \mathrm{hr}$ with purified M87 antibody in blocking buffer at concentration $250 \mathrm{ng} /$ well. The plates were then washed and incubated for $1 \mathrm{hr}$ with goat anti-mouse IgG (FC-specific)-peroxidase antibody (Sigma) diluted 1:10,000 in blocking buffer. Peroxidase activity was detected by colorimetric reaction using o-Phenylenediamine, which was stopped by $50 \mu \mathrm{l}$ of $1 \mathrm{~mol} / \mathrm{l} \mathrm{H}_{2} \mathrm{SO}_{4}$. Optical density (OD) was measured at $492 \mathrm{~nm}$ by the Synergy HT reader (BioTech Instruments, USA). Adjusted optical density was calculated by subtracting the OD of the negative antigen-coated wells and was set as $\mathrm{OD}_{\mathrm{NP}}$.

Enzyme-linked immunosorbent assay with human sera. Detection of nucleoprotein specific serum antibodies was carried out by sandwich ELISA. To obtain the best signal to noise ratio, different protocols were used. The maximum differences in optical density values between positive and negative sera were achieved by following this protocol: 96-well high binding plates were coated with NP-specific monoclonal antibody M87 at the final concentration of $250 \mathrm{ng}$ per well diluted in $0.05 \mathrm{~mol} / \mathrm{l}$ sodium carbonate-bicarbonate buffer ( $\mathrm{pH}$ 9.6). After incubation at $4^{\circ} \mathrm{C}$ overnight, the plates were washed three times with $0.1 \%$ Tween 20 in PBS. Then, each well of the plates was blocked for $1.5 \mathrm{hr}$ with $200 \mu \mathrm{l}$ of $10 \%$ milk in Tween PBS and washed 3 times. Subsequently, plates were incubated for 1 hr with protein extracts (BHK/MX and BHK21) in blocking buffer. The adjusted optical density of nucleoprotein in BHK/MX protein extracts set by the ELISA method described above was 0.36 . The 
plates were then washed and incubated with human serum samples diluted 1:40 in PBS in a total volume of $50 \mu$ l per well. In the case of determining anti-NP antibody titers, sera were serially diluted in PBS. Each serum was analysed in duplicates. After $1 \mathrm{hr}$ incubation, the plates were washed and subsequently incubated for 45 min with goat anti-human IgG (Fc-specific)-peroxidase $\mathrm{Ab}$ (Sigma) diluted 1:35,000 in blocking buffer. Peroxidase activity was detected by colorimetric reaction using o-Phenylenediamine, which was stopped by $50 \mu \mathrm{l}$ of $1 \mathrm{~mol} / \mathrm{l} \mathrm{H}_{2} \mathrm{SO}_{4}$. Optical density was measured at $492 \mathrm{~nm}$ by the Synergy HT reader. Adjusted OD was calculated by subtracting the OD of the negative antigen-coated wells.

Cut-offvalue determination. To find suitable internal positive and negative controls, human sera were analysed by immunoprecipitation and subsequent immunoblotting with NP-specific monoclonal antibody (described below). 25 sera, which had been proved negative with the immunoprecipitation test, were subsequently analysed in ELISA and the adjusted OD values obtained were then expressed as percent positivity (PP) of the average of 5 internal positive controls (selected based on the immunoprecipitation results). PP was calculated as follows: the mean of the adjusted OD value from duplicate samples divided by the mean value of the adjusted OD values of the five positive controls multiplied by 100 . The ELISA cut-off value, which served as the threshold between positive and negative serum samples, was determined as the mean PP value obtained with these 25 samples plus three standard deviations.

Indirect detection of anti-NP antibodies in human sera by immunoprecipitation. BHK/MX and BHK lysates (200 $\mu \mathrm{g}$ of proteins per sample) were precleared with $60 \mu \mathrm{l}$ of $50 \%$ suspension of Protein G-Sepharose (PGS; GE Healthcare, Sweden). Eight $\mu$ l of human serum were incubated with $192 \mu \mathrm{l}$ of $10 \%$ FCS in PBS for $1 \mathrm{hr}$ at room temperature. The mixture was further added to precleared cell lysates and immunocomplexes were allowed to form on rotating shaker at $4^{\circ} \mathrm{C}$ overnight. Immunocomplexes were then incubated with $80 \mu \mathrm{l}$ of $50 \%$ suspension of Protein G-Sepharose in PBS for $3 \mathrm{hr}$ at $4^{\circ} \mathrm{C}$. Beads were washed six times with PBS, immunoprecipitated proteins were subjected to SDS-PAGE and transferred onto a polyvinylidene difluoride membrane (Immobilon, Millipore, USA). Membranes were probed with specific anti-NP monoclonal antibody M87 in medium, washed with washing buffer $(0.2 \%$ Nonidet P-40 in PBS), and finally incubated with secondary goat antimouse-peroxidase $\mathrm{Ab}$ for $1 \mathrm{hr}$. After an additional washing step, immunoblots were visualised using the ECL detection system.

Indirect immunofluorescence antibody test. To prepare antigen for the IFA, mixture of BHK/MX and BHK21 (1:1) cells were grown on glass coverslips. After removing the medium and washing with PBS, the cells were fixed with ice-cold methanol at $-20^{\circ} \mathrm{C}$ for $5 \mathrm{~min}$. Nonspecific binding was blocked by incubation with $3 \%$ bovine serum albumin (BSA) in PBS for $1 \mathrm{hr}$ at room temperature. Subsequently, the cells were incubated with human serum diluted 1:40 in 1\% BSA for $1 \mathrm{hr}$ at room temperature. After washing five times with $0.1 \%$ Tween 20 for $5 \mathrm{~min}$, the cells were incubated with anti-human/Alexa Fluor 568 secondary antibody and M16/ Alexa Fluor 488 antibody (diluted 1:1,700 and 1:190 in 1\% BSA respectively) for $1 \mathrm{hr}$ at $37^{\circ} \mathrm{C}$. After washing, cells were mounted on slides with Fluoroshield mounting medium with DAPI (Abcam, UK) and analysed by confocal microscope LSM 510 META (Zeiss, Germany).

Calculations of clinical sensitivity and specificity of ELISA and IFA. As already mentioned, there is no commercially available and routinely used ELISA test for the detection of LCMV-specific antibodies, which could be considered as a "gold standard". Therefore we decided to validate our new ELISA test and standard IFA against immunoprecipitation, which in our hands served as the "gold standard" method.

Clinical sensitivity was calculated as: [number of true positive sera/(number of true positive sera+number of false negative sera) $]^{\star} 100 \%$.

Clinical specificity was calculated as: [number of true negative sera/(number of true negative sera+number of false negative sera) $]^{\star} 100 \%$.

\section{Results}

\section{ELISA protocol optimization}

To obtain maximum differences in the OD values of the positive and negative sera, different ELISA formats and various titration protocols for the antibody and antigen were analysed. The best results were achieved when instead of coating the plates with NP containing cell lysate, the monoclonal NP-specific Ab M87 was used (Fig. 1a). To determine the appropriate concentration of purified M87 antibody and NP containing BHK/MX protein extracts pre-

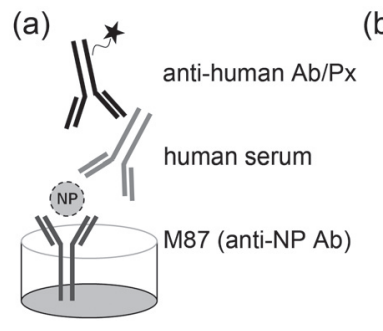

(b)

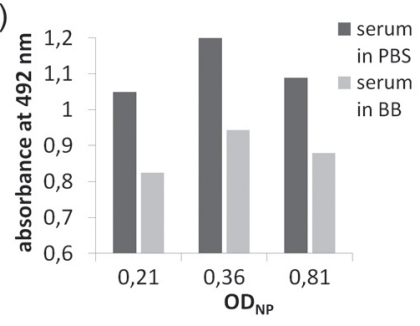

Fig. 1

Development of ELISA

(a) ELISA scheme. Wells were coated with monoclonal antibody M87 (specific to nucleoprotein (NP) of LCMV). Nucleoprotein present in BHK/ MX cell lysates served as antigen. Anti-nucleoprotein IgG antibodies in human sera were detected by peroxidase-labelled anti-human antibody. (b) Anti-NP IgG-positive human serum KH ELISA results. The wells were coated with $250 \mathrm{ng}$ of purified M87 antibody, followed by incubation with $\mathrm{BHK} / \mathrm{MX}$ protein extracts with ODs corresponding to NP concentrations of $0.21,0.36$ and 0.81 . BHK21 and antigen-positive BHK/MX lysate concentrations were equivalent. KH serum was diluted to 1:40 in PBS or in blocking buffer (BB; $10 \%$ milk in $0.2 \%$ Tween-20 in PBS). Adjusted optical densities were calculated by subtraction of the appropriate unspecific background at $492 \mathrm{~nm}$. 
pared from BHK21 cells persistently infected with LCMV strain MX, we tested four different concentrations of M87 $(200,250,300$, and $350 \mathrm{ng} /$ well $)$ diluted in carbonate-bicarbonate buffer and three concentrations of $\mathrm{BHK} / \mathrm{MX}$ protein extracts, in which ODs corresponding to the amount of $\mathrm{NP}\left(\mathrm{OD}_{\mathrm{NP}}\right)$ were $0.21,0.36$ and 0.81 . Concentrations of BHK21 protein extracts coincided with concentrations of antigen-positive BHK/MX lysates. Positive control human serum $\mathrm{KH}$ was diluted in blocking buffer $(10 \%$ milk in Tween-PBS) or in PBS and tested in duplicate for each Ab-Ag combination. Comparison of blocking buffers (10\% milk in $0.1 \%$ Tween 20 in PBS and 10\% FCS in Tween-PBS) showed that $10 \%$ milk was as effective as $10 \%$ FCS. Analysis of anti-human-peroxidase secondary antibody incubation times proved that shortened incubation (45 min instead of $1 \mathrm{hr}$ ) led to reduced background signal. The adjusted OD was calculated by subtracting the OD of the BHK21protein extract-coated wells from that of the corresponding BHK/MX wells. The observed optical densities (Fig. 1b) showed that the best signal to noise ratio was provided with $\mathrm{OD}_{\mathrm{NP}}=0.36$ and serum diluted in PBS. Since differences between M87 concentrations did not significantly alter the results (data not shown), we decided to use $250 \mathrm{ng}$ of antibody per well in the subsequent assays.

\section{Determination of cut-off value}

To differentiate between positive and negative sera in ELISA, we had to determine the cut-off value of absorbance. For this purpose we decided to use another anti-NP IgG antibody detecting method - immunoprecipitation. IgG antibodies in human sera $(8 \mu \mathrm{l})$ were bound to protein $\mathrm{G}$ and after incubation with NP-containing BHK/MX lysate, nucleoprotein was detected by Western blot using specific monoclonal antibody M87. We thus indirectly confirmed the presence of anti-NP IgGs in the sera. Based on the immunoprecipitation results (Fig. 2), we selected 25 negative

\section{\begin{tabular}{lll}
- & $\mathrm{NP}$ \\
\hline
\end{tabular} \\ $\underline{B / X \quad B} B / X \quad B \quad B / X \quad B \quad B / X \quad B \quad B / X \quad B$ \\ $\overline{\text { serum }} \overline{\text { serum }} \overline{\text { serum }} \overline{M 16} \frac{}{\varnothing}$ \\ Fig. 2}

Immunoprecipitation with human sera

BHK/MX (B/X) and BHK21 (B) cell lysates were incubated with human sera, followed by the binding of the immunocomplexes to Protein GSepharose (PGS). Subsequently, the presence of anti-NP IgG antibodies was detected with anti-NP monoclonal antibody M87 by Western blot. Cell lysates incubated with anti-NP monoclonal antibody M16 and PGS and cell lysates incubated only with PGS served as controls. Using this method, we were able to differentiate positive (strongly positive serum +++ , weakly positive serum + ) and negative (-) sera.

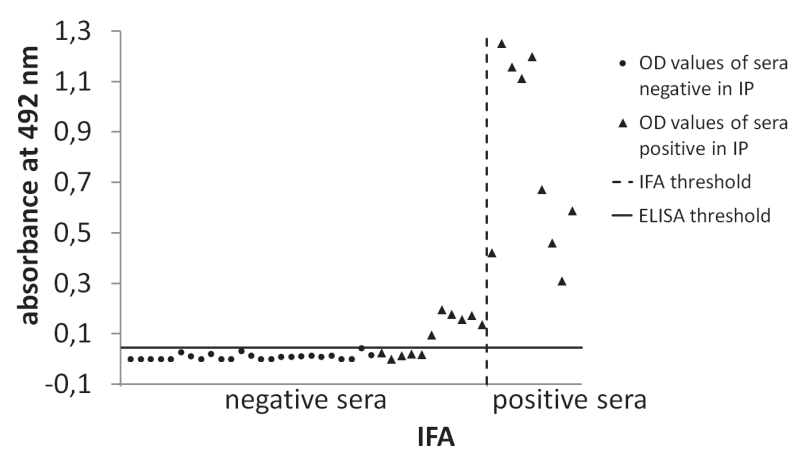

Fig. 3

Testing of 45 sera by ELISA, IFA and "gold standard" immunoprecipitation

Human sera (diluted 1:40 in PBS) were tested by the developed ELISA, standard IFA and $8 \mu \mathrm{l}$ of each serum were analysed also by immunoprecipitation (IP). Threshold OD value for ELISA was 0.044. The results were used for clinical specificity and sensitivity calculations of the ELISA and IFA methods (Table 1).

and 5 positive sera, which we used for the determination of the ELISA cut-off value that served as the threshold between positive and negative serum samples. The OD average value which resulted from ELISA testing of negative sera was 0.009 . The average of adjusted ODs of 5 internal positive controls was 1.028. Subsequently, values were changed to percent positivity (PP). The cut-off value was determined as the mean percent positivity obtained with 25 negative samples plus three standard deviations. Using this method, the cut-off value was determined to be $4.28 \%$, which represents OD at 0.044 and was used for subsequent ELISA analyses.

Moreover, we titrated all 5 sera, which were used as positive controls in the cut-off determination and found that anti-NP IgG titers in these sera were 800, 1,600, 5,000, 10,000 , and 15,000.
Table 1. Calculation of clinical sensitivity and specificity of ELISA and IFA with immunoprecipitation as "gold standard" (20 sera positive and 25 negative)

\begin{tabular}{llcl}
\hline & \multicolumn{3}{c}{ Clinical sensitivity } \\
\hline ELISA & true positive & 15 & {$[15 /(15+5)]^{\star} 100=\mathbf{7 5 \%}$} \\
& false negative & 5 & \\
\hline IFA & true positive & 9 & {$[9 /(9+11)]^{\star} 100=\mathbf{4 5} \%$} \\
& false negative & 11 & \\
\hline \multirow{4}{*}{ Clinical specificity } & \\
\hline ELISA & false positive & 0 & {$[25 /(25+0)]^{\star} 100=\mathbf{1 0 0 \%}$} \\
& true negative & 25 & \\
\hline IFA & false positive & 0 & {$[25 /(25+0)]^{\star} 100=\mathbf{1 0 0} \%$} \\
& true negative & 25 & \\
\hline
\end{tabular}


Determination of clinical ELISA sensitivity and specificity and comparison with IFA

After optimization of the ELISA method, we determined its clinical sensitivity and specificity. For this purpose, 25 negative and 20 positive sera (based on the immunoprecipitation results) were tested by a new ELISA test. To compare the developed ELISA to another standard method, we analysed the same sera with IFA (Fig. 3). As shown in Table 1, clinical sensitivity of our ELISA is $75 \%$, since we were able to detect 15 positive sera out of 20 and clinical specificity is $100 \%$, since we detected as negative all sera, which were

(a)
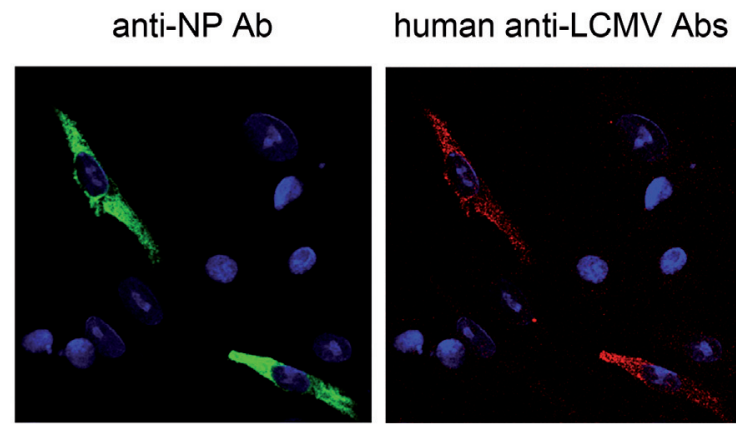

(b)
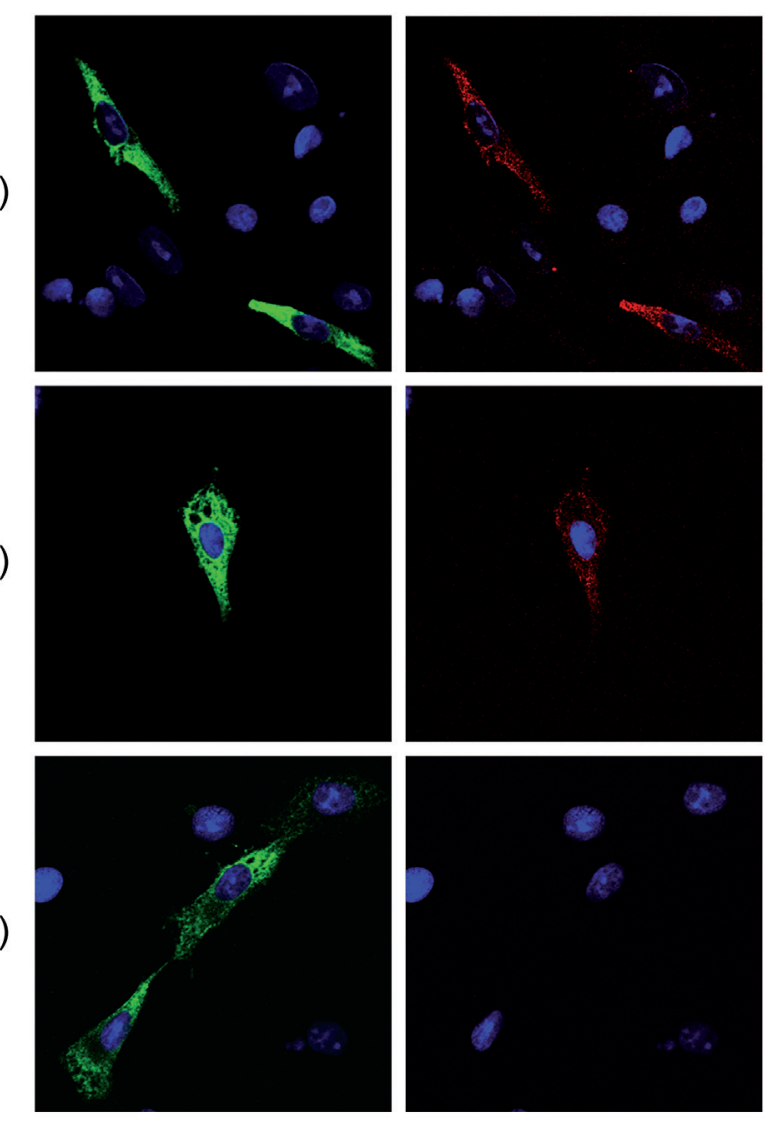

Fig. 4

Indirect immunofluorescence assay with human sera

Mixture of BHK21 cells and BHK21 cells persistently infected with LCMV strain MX was incubated with human sera diluted to 1:40. Anti-LCMV IgG antibodies were visualised by anti-human Ab labelled with Alexa Fluor 568 (red). To simultaneously identify cells infected with the virus, nucleoprotein was detected by monoclonal antibody M16 labelled with Alexa Fluor 488 (green). (a) IFA with positive human serum KH. (b) IFA with strongly positive serum $(+++$; titer of anti-NP $\operatorname{IgG} 1,600)$ according to ELISA results. (c) IFA with weakly positive serum (+; titer of anti-NP IgG 40) according to ELISA results.

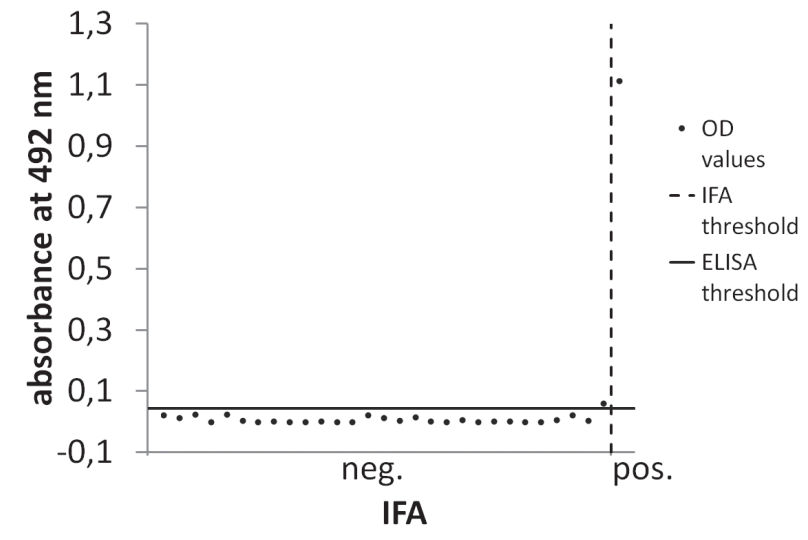

Fig. 5

Testing of multiorgan donor sera

30 sera were analysed by the newly-established ELISA and standard IFA. Threshold OD value for ELISA was 0.044. Results were used for the calculation of the total coincidence rate of the two tests.

found to be negative by immunoprecipitation. On the other hand, clinical sensitivity of IFA is $45 \%$ (we detected 9 sera as positive out of 20 ) and specificity is $100 \%$.

\section{Testing of multiorgan donor sera}

Furthermore, we used our ELISA for the detection of anti-NP antibodies in 30 sera collected from multiorgan donors. Based on the obtained adjusted OD values, calculated percent positivity, and comparison to the cut-off value, we designated 2 sera as positive and 28 as negative. Positive sera were subsequently titrated and the antibody titer of a strongly positive serum was estimated 1,600 and of a weakly positive serum 40 .

The same sera were then analysed with IFA. Representative samples of IFA, including the positive serum $\mathrm{KH}$ (Fig. 4a) are shown in Fig. 4. Only 1 out of 30 clinical samples was found positive using the IFA method (Fig. 4b). One weakly positive serum in ELISA (anti-NP IgG titer 40) was negative in IFA

Table 2. ELISA and IFA results comparison

\begin{tabular}{ccccc}
\hline & & \multicolumn{3}{c}{ IFA } \\
\cline { 3 - 5 } & & positive & negative & total \\
\hline \multirow{3}{*}{ ELISA } & positive & 1 & 1 & 2 \\
& negative & 0 & 28 & 28 \\
& total & 1 & 29 & 30 \\
\hline
\end{tabular}

Compared to IFA, the total coincidence rate $(=$ detection results in the same number/total samples): $[(1+28) / 30]^{\star} 100=96.67 \%$. 
(Fig. 4c). Comparison of the ELISA to the IFA results showed a total coincidence rate of $96.67 \%$ (Fig. 5; Table 2).

\section{Discussion}

Lymphocytic choriomeningitis virus is a human pathogen, which, as has been recently shown, possesses a great risk to several groups of people. Congenital infection may lead to spontaneous abortion (Bonthius et al., 2007), and previously documented cases of transplant-associated infections of immunocompromised individuals showed fatal outcomes in most patients (Fischer et al., 2006; CDC, 2008; Palacios et al., 2008; MacNeil et al., 2012; Schafer et al., 2014). In the case of congenital infection, the virus may not be detected after the infant is born, but specific IgGs are present in the mother's and infant's sera. The most common methods for the detection of specific anti-LCMV antibodies in sera are ELISA and IFA (OIE, 2006). The complement fixation test is relatively insensitive. Since there are no commercial ELISA kits for the detection of such antibodies available for routine use, we developed a method serving this purpose. For the ELISA tests, the antigen is usually prepared from cells infected with LCMV (Marrie and Saron, 1998; Riera et al., 2005). During such preparation of the antigen, handling of infectious LCMV is required, which is necessary to perform in a biosafety containment facility. In our ELISA, we used nucleoprotein-containing protein extracts from MXinfected BHK21 cells as antigen. The advantage of the LCMV strain MX is that it causes persistent infection of cells, and therefore provides cell lysates containing large amounts of antigen. Moreover, it does not form distinct virions released into the medium, and its transmission to uninfected cells in normoxia is mediated only by direct cell-cell contact (Reiserová et al., 1999; Laposova et al., 2013). This makes the handling of MX (and MX-infected cells) safer than handling other strains of LCMV. Also, ELISA with recombinant LCMV-NP as antigen has been previously reported by several groups (Homberger et al., 1995; Takimoto et al., 2008). In this case, either crude extracts from insect cells infected with recombinant baculovirus (Homberger et al., 1995) or LCMV-NP obtained by purification with high molar urea were used as antigen (Takimoto et al., 2008). According to published data, the ELISA assay using purified antigen was more sensitive in the detection of anti-LCMV antibodies. In our assay, we used an NP-capturing monoclonal antibody for the purification of LCMV-NP directly in the multiwell plate. Preparation of antigen by this method is more convenient and less time consuming in comparison to preparation of purified recombinant LCMV-NP. The use of the monoclonal anti-NP antibody in the first step also increases ELISA specificity and leads to a reduced background signal. By our ELISA assay, we detect specific anti-NP antibodies in acute, as well as persistent infection because nucleoprotein is highly produced in both, in contrast to the viral glycoprotein, the production of which is limited in the persistent state (Francis and Southern, 1988). To distinguish positive and negative sera, we had to set a cut-off value. According to literature, there are many methods for determination of the ELISA threshold. We decided to use calculations based on the results of immunoprecipitation, since it is a very sensitive method, and it allowed us to identify anti-NP antibody-positive and -negative sera by Western blot. Subsequently, the sera were tested by ELISA, and their absorbances were used for the cut-off value calculation where we set stringent conditions to avoid false positive results. After determining the threshold, we calculated clinical sensitivity and specificity of the newly-developed ELISA and standard IFA. Results show, that clinical specificity of both methods is $100 \%$, but clinical sensitivity of ELISA is $30 \%$ higher than that of IFA. Next, we analysed sera from multiorgan donors since this is an interesting group of samples based on the recently described LCMV transmission through organ transplants (Fischer et al., 2006; CDC, 2008; Palacios et al., 2008; MacNeil et al., 2012; Schafer et al., 2014). We identified 2 of those sera as positive by our new ELISA method. Comparison of these results to the IFA method showed that the newly-established ELISA is more sensitive, since a weakly positive serum detected by ELISA (titer of anti-NP IgG 40) was negative by IFA. With this method, we were able to detect only the serum with anti-NP IgG titer 1,600. Moreover, in our experience, the testing of human sera by the IFA method is accompanied by high background, which is significantly reduced in ELISA.

In summary, our ELISA assay is very sensitive and enables the detection of NP-specific antibodies, which can be used not only for determining the prevalence of LCMV-specific antibodies in human populations for scientific purposes, but also for the diagnostic testing of LCMV infection.

Acknowledgements. This project was supported by grant from the Scientific Grant Agency of the Ministry of Education of the Slovak Republic and the Slovak Academy of Sciences VEGA 2/0053/15.

\section{References}

Ackermann R (1973): Epidemiologic aspects of lymphocytic choriomeningitis in man. In Lehmann-Grube F: Lymphocytic Choriomeningitis Virus and Other Adenoviruses, Berlin, Springer-Verlag, pp. 233-237. http://dx.doi. org/10.1007/978-3-642-65681-1_21

Barton LL, Mets MB (2001): Congenital lymphocytic choriomeningitis virus infection: decade of rediscovery. Clin. Infect. Dis. 33, 370-374. http://dx.doi.org/10.1086/321897

Barton LL, Mets MB, Beauchamp CL (2002): Lymphocytic choriomeningitis virus: emerging fetal teratogen. Am. J. Obstet. 
Gynecol. 187, 1715-1716. http://dx.doi.org/10.1067/ mob.2002.126297

Bonthius DJ, Wright R, Tseng B, Barton L, Marco E, Karacay B, Larsen PD (2007): Congenital lymphocytic choriomeningitis virus infection: spectrum of disease. Ann. Neurol. 62, 347-355. http://dx.doi.org/10.1002/ana.21161

CDC (2008): Brief report: Lymphocytic choriomeningitis virus transmitted through solid organ transplantation-Massachusetts. MMWR Morb. Mortal. Wkly. Rep. 57, 799-801.

Dobec M, Dzelalija B, Punda-Polic V, Zoric I (2006): High prevalence of antibodies to lymphocytic choriomeningitis virus in a murine typhus endemic region in Croatia. J. Med. Virol. 78, 1643-1647. http://dx.doi.org/10.1002/ imv.20749

Fischer SA, Graham MB, Kuehnert MJ, Kotton CN, Srinivasan A, Marty FM, Comer JA, Guarner J, Paddock CD, DeMeo DL, Shieh W-J, Erickson BR, Bandy U, DeMaria A Jr., Davis JP, Delmonico FL, Pavlin B, Likos A, Vincent MJ, Sealy TK, Goldsmith CS, Jernigan DB, Rollin PE, Packard MM, Patel M, Rowland C, Helfand RF, Nichol ST, Fishman JA, Ksiazek T, Zaki SR, the LCMV in Transplant Recipients Investigation Team (2006): Transmission of lymphocytic choriomeningitis virus by organ transplantation. N. Engl. J. Med. 354, 2235-2249. http://dx.doi. org/10.1056/NEJMoa053240

Francis SJ, Southern PJ (1988): Deleted viral RNAs and lymphocytic choriomeningitis virus persistence in vitro. J. Gen. Virol. 69, 1893-1902. http://dx.doi.org/10.1099/0022-131769-8-1893

Homberger FR, Romano TP, Seiler P, Hansen GM, Smith AL (1995): Enzyme-linked immunosorbent assay for detection of antibody to lymphocytic choriomeningitis virus in mouse sera, with recombinant nucleoprotein as antigen. Lab. Anim. Sci. 45, 493-496.

Jamieson DJ, Kourtis AP, Bell M, Rasmussen SA (2006): Lymphocytic choriomeningitis virus: An emerging obstetric pathogen? Am. J. Obst. and Gynecology 194, 1532-1536. http://dx.doi.org/10.1016/j.ajog.2005.11.040

Kallio-Kokko H, Laakkonen J, Rizzoli A, Tagliapietra V, Cattadori I, Perkins SE, Hudson PJ, Cristofolini A, Versini W, Vapalahti O, Vaheri A, Henttonen H (2006): Hantavirus and arenavirus antibody prevalence in rodents and humans in Trentino, Northern Italy. Epidemiol. Infect. 134, 830-836. http://dx.doi.org/10.1017/S0950268805005431

Laposova K, Pastorekova S, Tomaskova J (2013): Lymphocytic choriomeningitis virus: invisible but not innocent. Acta Virol. 57, 160-170. http://dx.doi.org/10.4149/ av $2013 \quad 02 \_160$

Lledó L, Gegundez MI, Saz JV, Bahamontes N, Beltran M (2003): Lymphocytic choriomeningitis virus infection in a province of Spain: Analysis of sera from the general population and wild rodents. J. Med. Virol. 70, 273-275. http://dx.doi. org/10.1002/jmv.10389

MacNeil A, Stroher U, Farnon E, Campbell S, Cannon D, Paddock CD, Drew CP, Kuehnert M, Knust B, Gruenenfelder R, Zaki SR, Rollin PE, Nichol ST (2012): Solid organ transplant-associated lymphocytic choriomeningitis,
United States. Emerg. Infect. Dis. 18, 1256-1262. http:// dx.doi.org/10.3201/eid1808.120212

Marrie TJ, Saron MF (1998): Seroprevalence of lymphocytic choriomeningitis virus in Nova Scotia. Am. J. Trop. Med. Hyg. 58, 47-49.

Mets MB, Barton LL, Khan AS, Ksiazek TG (2000): Lymphocytic choriomeningitis virus: an underdiagnosed cause of congenital chorioretinitis. Am. J. Ophthalmol. 130, 209-215. http://dx.doi.org/10.1016/S0002-9394(00)00570-5

OIE - World Organisation for Animal Health (2006): Lymphocytic choriomeningitis. pp. 1-5.

Palacios G, Druce J, Du L, Tran T, Birch C, Briese T, Conlan S, Quan PL, Hui J, Marshall J, Simons JF, Egholm M, Paddock CD, Shieh WJ, Goldsmith CS, Zaki SR, Catton M, Lipkin WI (2008): A new arenavirus in a cluster of fatal transplantassociated diseases. N. Engl. J. Med. 358, 991-998. http:// dx.doi.org/10.1056/NEJMoa073785

Park JY, Peters CJ, Rollin PE, Ksiazek TG, Gray B, Waites KB (1997a): Development of a reverse transcriptionspolymerase chain reaction assay for diagnosis of lymphocytic choriomeningitis virus infection and its use in a prospective surveillance study. J. Med. Virol. 51, 107-114. http://dx.doi.org/10.1002/(SICI)1096-9071(199702)51:2<107::AID-JMV4>3.0.CO;2-B

Park JY, Peters CJ, Rollin PE, Ksiazek TG, Katholi CR, Waites KB, Gray B, Maetz HM, Stephensen CB (1997b): Age distribution of lymphocytic choriomeningitis virus serum antibody in Birmingham, Alabama: evidence of a decreased risk of infection. Am. J. Trop. Med. Hyg. 57, 37-41.

Pastorekova S, Zavadova Z, Kostal M, Babusikova O, Zavada J (1992): A novel quasi-viral, MaTu, is a two-component system. Virology 187, 620-626. http://dx.doi. org/10.1016/0042-6822(92)90464-Z

Reiserová L, Kaluzová M, Kaluz S, Willis AC, Závada J, Závodská E, Závadová Z, Čiampor F, Pastorek J, Pastoreková S (1999): Identification of MaTu-MX agent as a new strain of lymphocytic choriomeningitis virus (LCMV) and serological indication of horizontal spread of LCMV in human population. Virology 257, 73-83. http://dx.doi. org/10.1006/viro.1999.9638

Riera L, Castilo E, Saavedra MC, Priotto J, Sottosanti J, Polop J, Ambrosio AM (2005): Serological study of the lymphocytic choriomeningitis virus (LCMV) in an Inner City of Argentina. J. Med. Virol. 76, 285-289. http://dx.doi. org/10.1002/jmv.20357

Schafer IJ, Miller R, Ströher U, Knust B, Nichol ST, Rollin PE; Centers for Disease Control and Prevention (CDC) (2014): Notes from the field: a cluster of lymphocytic choriomeningitis virus infections transmitted through organ transplantation - Iowa. MMWR Morb. Mortal. Wkly. Rep. 63, 249.

Takimoto K, Taharaguchi M, Morikawa S, Ike F, Yamada YK (2008): Detection of the antibody to lymphocytic choriomeningitis virus in sera of laboratory rodents infected with viruses of laboratory and newly isolated strains by ELISA using purified recombinant nucleoprotein. Exp. Anim. 57, 357-365. http://dx.doi.org/10.1538/expanim.57.357 
Tomaskova J, Oveckova I, Labudova M, Lukacikova L, Laposova K, Kopacek J, Pastorekova S, Pastorek J (2011): Hypoxia induces the gene expression and extracellular transmission of persistent lymphocytic choriomeningitisvirus. J. Virol. 85, 13069-13076. http://dx.doi.org/10.1128/JVI.00829-11

van der Zeijst BAM, Noyes BE, Mirault ME, Parker B, Osterhaus ADME, Swyryd EA, Bleumink N, Horzinek MC, Stark
GR (1983): Persistent infection of some standard cell lines by LCMV: transmission of infection by an intracellular agent.489 J. Virol. 48, 249-261.

Závada J, Závadová Z, Malíř A, Kočent A (1972): VSV pseudotype produced in cell line derived from human mammary carcinoma. Nat. New. Biol. 240, 124-125. http://dx.doi. org/10.1038/newbio240124a0 